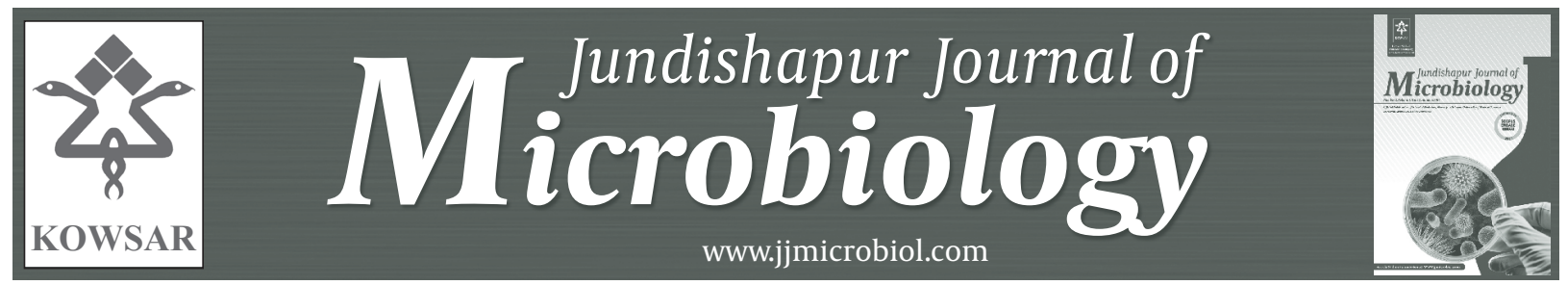

\title{
Distribution of Hepatitis C Virus Genotypes Among Chronic Infected Inject- ing Drug Users in Tehran, Iran
}

\author{
Fahimeh Ranjbar Kermani ${ }^{1}$, Zohreh Sharifi ${ }^{1, *}$, Fereshteh Ferdowsian ${ }^{1}$, Zahrah Paz ${ }^{1}$, Mahsa \\ Zamanian $^{1}$
}

${ }^{1}$ Blood Transfusion Research Center, High Institute for Research and Education in Transfusion Medicine, Tehran, IR Iran

*Corresponding author: Zohreh Sharifi, Blood Transfusion Research Center, High Institute for Research and Education in Transfusion Medicine, Tehran, IR Iran. Tel:+98-2188601501-30, Fax:+98-2188601555, E-mail: z.sharifi@ibto.ir.

\begin{abstract}
A B S T R A C T
Background: Hepatitis C virus (HCV) is the main cause of infection that has the potential to cause chronic liver disease. Injecting drug users (IDUs) have a key role in HCV transmission in Iran. Knowledge of the distribution of various genotypes is essential for successful future research and control strategies.

objectives: The aim of this study was to identify HCV genotypes among chronic infected injecting drug users (IDUs) in Tehran, Iran. Patients and Methods: In this cross sectional study, we investigated HCV genotypes among 36 plasma samples from HCV infected IDUs (35 male and 1female, mean age: 33.67, and age range 20-62 years), referred to Research Center of Iranian Blood Transfusion Organization(IBTO) in Tehran from December 2008 to March 2009.HCV Genotyping was performed using type-specific primers.

Results: Genotypes 3a, 1a and 1b were found in $58.3 \%, 25 \%$ and $16.7 \%$ patients, respectively.

Conclusions: Our study demonstrated the high prevalence of genotype 3 a among injecting drug users, which is also found in Europe and United states.
\end{abstract}

Keywords: Hepatitis C virus; HCV Genotypes; Injecting Drug Users; Iran

Copyright ( $\odot$ 2013, Ahvaz Jundishapur University of Medical Sciences; Published by Kowsar Corp.

-Article type: Research Article; Received: 17 Apr 2012, Revised: 20 Jun 2012, Accepted: 03 Jul 2012; DOI: 10.5812/jjm.5191

-Implication for health policy/practice/research/medical education:

High prevalence of genotype 3a among injecting drug users (IDUs) due to the possibility of the changing of dominant circulating viruses in our community.

Please cite this paper as:

Ranjbar Kermani F, Sharifi Z, Ferdowsian F, Paz Z , Zamanian M. Distribution of Hepatitis C Virus Genotypes Among Chronic Infected Injecting Drug Users in Tehran, Iran. Jundishapur J Microbiol. 2013;6(3):265-8. DOI: 10.5812/jjm.5191

Copyright (C) 2013, Ahvaz Jundishapur University of Medical Sciences; Published by Kowsar Corp.

This is an Open Access article distributed under the terms of the Creative Commons Attribution License (http://creativecommons.org/licenses/by/3.0), which permits unrestricted use, distribution, and reproduction in any medium, provided the original work is properly cited. 


\section{Background}

Hepatitis C virus (HCV) infection is a worldwide problem in health. HCV is a major cause of chronic liver disease, hepatocellular carcinoma, and the single most common indication for liver transplantation. Approximately 2-3 percent of the world's population is infected with HCV $(1,2)$.The most recent WHO estimate of the prevalence of $\mathrm{HCV}$ infection is $2 \%$ (ranging from $0.6 \%$ to $2.3 \%$ ) in North America, Northern and Western Europe, and Australia. The prevalence of infection in healthy blood donors ranges from $0.01-0.02 \%$ in Northern Europe, and 1-1.5\% in Southern Europe, to 6.5\% in parts of equatorial Africa (3).

The prevalence of HCV infection is about $0.12 \%$ in blood donors in Iran (4). It seems that the prevalence of HCV infection is less than $1 \%$ in our general population (5), but the infection is emerging due to injecting drug users (IDUs) and needle sharing among addicts. HCV is a blood-borne pathogen and can be transmitted through blood products and infected syringes, and infection rates are typically high among IDUs. Nowadays, injecting drug using is the major risk factor for HCV infection (6).The incidence of HCV infected IDUs varies from $31 \%$ to $89 \%$ in different parts of the word $(7,8)$. A study reported that the rate of HCV antibody positivity among IDUs is $52 \%$ in Tehran and it is still expanding (9).

A recent international standardization of HCV nomenclature proposed a classification into 6 genotypes (1 to 6) and more than 70 subtypes. The different genotypes display up to $70 \%$ sequence similarity, whereas subtypes vary by more than $20 \%$ (10). Genotyping is useful tool for investigating outbreaks and for understanding the epidemiology of the infection. Clinically, genotyping of HCV is important for predicting treatment responses and for determining the duration of antiviral therapy. Response to interferon (IFN)-based therapies in patients infected with HCV genotype 1 and 4 is much lower than in genotypes 2 and 3 (11).Infection with genotype 1 may proceed rapidly to severe form of chronic hepatocellular, cirrhosis, and hepato cellular carcinoma, when compared with genotypes 2 and 3 (12). Although genotypes 1, 2 and 3 are responsible for more than $90 \%$ of the infection in North and South America and Japan, prevalence and distribution of HCV genotypes are linked to geographical region and the route of viral transmission (12-14).

In a study, all isolated from Iranian patients have been classified to five groups: $1 \mathrm{a}$ (52.88\%), 1b (14.01\%), 3a (27.57\%) , 2a (2.1\%), and 4 (3.44\%) (15). A similar study on Iranian patients revealed that $1 \mathrm{a}, 1 \mathrm{~b}$ and $3 \mathrm{a}$ were predominant genotypes with an overall rate of $61.2 \%, 13.8 \%$, and $25 \%$, respectively (16). Sharifi et al. showed that the prevalence of HCV genotypes in 103 blood donors and 64 patients are as following: The highest frequency was for genotype 1a, with 53 and 34 (51.5\% versus 53.1\%) of subjects in blood donors and patients respectively (17). Genotype $3 \mathrm{a}$ and $1 \mathrm{~b}$ were the other frequent genotypes with 4 and 16 (3.9\% versus
$25 \%$ ) and 39 and 10 (37.9\% versus $15.6 \%$ ) subjects, respectively. Molecular epidemiology studies have shown that genotype 3a is significantly associated with transmission through injecting drug use in industrial countries (18). Although there are many reports describing the distribution of HCV genotype in different parts of Iran, but it seems that there are few published information about the distribution of HCV genotype in different groups of Iranian HCV infected patients such as IDUs within the different reports. For example, Samimi Rad et al. in a phylogenetic analysis of NS5B region testing showed younger IDUs had more frequently subtype 3a (54\%) (19). Kabir et al. tested HCV genotyping in IDUs, and showed that genotypes 1a with $18(40 \%)$ and 3a with $17(37 \%)$ are the most frequent in this group of Iranian patients (20).

\section{Objectives}

Due to the possibility of the changing of dominant circulating viruses in community, it is important to determine HCV genotype in different geographical regions and routes of transmission, for both epidemiological purposes and patients' management. In this study we investigated HCV genotypes among HCV-infected IDUs, referred to Research Center of Iranian Blood Transfusion Organization (IBTO), Tehran, Iran.

\section{Patients and Methods}

This is a cross-sectional study of 36 HCV infected IUDs (35 male and 1 female, mean age 33.67), referred to IBTO, Tehran from December 2008 to March 2009. HCV infection in patients had been confirmed by positive results in HCV-Ab and HCV-RNA tests. Blood samples were centrifuged and plasma samples were aliquoted and stored at $-70{ }^{\circ} \mathrm{C}$ before testing. All samples were tested for HCV genotyping by primer specific method as explained below.

\subsection{RNA Extraction}

HCV-RNA was isolated from $250 \mu \mathrm{l}$ of plasma using TriPure Isolation Reagent (Roche Applied Science, Mannheim, Germany) accoriding to manufacturer's instruction. The RNA was eluted in $20 \mu$ l elution buffer and then $5 \mu \mathrm{l}$ were used for cDNA synthesis.

\subsection{HCV Genotyping}

Genotypes were determined by performing PCR, using specific primers for the target core region of the HCV genome, with two separate reaction tubes containing different primer mixes. This method helps for the determination of genotypes $1 \mathrm{a}, 1 \mathrm{~b}, 2 \mathrm{a}, 2 \mathrm{~b}, 3 \mathrm{a}, 3 \mathrm{~b}, 4,5 \mathrm{a}$, and $6 \mathrm{a}$ in separate reaction tubes (21). For the reverse transcription -PCR, $1 \mu \mathrm{g}$ of the extracted nucleic acid, $1.5 \mathrm{mM} \mathrm{MgCl}$, 1X PCR buffer containing $10 \mathrm{mM}$ Tris- $\mathrm{HCl}, 50 \mathrm{mM} \mathrm{KCl} \mathrm{(pH}$ 8.3) $10 \mathrm{mM}$ DTT, $10 \mathrm{nmol}$ of each dNTP, and $25 \mu \mathrm{M}$ of outer primers in a total volume of $10 \mu \mathrm{l}$ were used for the reac- 
tion. The reaction mixture was incubated at $95^{\circ} \mathrm{C}$ for 5 min before the addition of $20 \mathrm{U}$ Rib nuclease inhibitor (Roche Molecular Biochemical) and 20 U of reverse transcriptase from avian myeloblastosis virus (Roche Molecular Biochemical Company, Mannheim, Germany). After $60 \mathrm{~min}$ at $42^{\circ} \mathrm{C}$, the reaction was heated for $5 \mathrm{~min}$ at $95^{\circ} \mathrm{C}$. Briefly, $2 \mu \mathrm{l}$ of the cDNA was amplified in a $50 \mu \mathrm{l}$ reaction volume containing $1.5 \mathrm{mM} \mathrm{MgCl}$, 10 mMTris- $\mathrm{HCl}, 50 \mathrm{mM}$ $\mathrm{KCl}$, and $2.5 \mu \mathrm{M}$ of both sense and antisense outer primers.

The first round of amplification was performed under the following conditions: twenty cycles of amplification at $94^{\circ} \mathrm{C}$ for $1 \mathrm{~min}, 45^{\circ} \mathrm{C}$ for $1 \mathrm{~min}$, and $72^{\circ} \mathrm{C}$ for $1 \mathrm{~min}$; followed by an additional 20 cycles of $94^{\circ} \mathrm{C}$ for $1 \mathrm{~min}, 60^{\circ} \mathrm{C}$ for $1 \mathrm{~min}$, and $72^{\circ} \mathrm{C}$ for $1 \mathrm{~min} .1 \mu \mathrm{L}$ of first round product was taken as input for the second round PCR. The products of the second round PCR were run into a gel electrophoresis with a $2 \%$ agarose gel. Samples were assigned to their genotypes based on the band size of the final amplified product as recommended (21). The plasma with different genotypes of HCV (BIO Quality control reagent Rijswijk, The Netherlands) was used as positive control for detection of different genotypes of HCV.

\subsection{Statistical Analysis}

Descriptive statistics including mean age and genotype frequency distributions were computed. All analysis were done using SPSS version 16.0.

\section{Results}

A total of 36 patients were studied, $97.2 \%$ of them were male and $2.8 \%$ of them were female, and aged between 20 and 62 years (mean age 33.67). In this present study, only 3 subtypes were detected. There was not any patient with mixed infection or undetected genotype. 21 (58.3\%) HCV infected IUDs were infected with genotype 3a, therefore 3a was predominant, followed by genotype 1a with 9 (25\%), and genotype 1 b with 6 (16.7\%).

\section{Discussion}

Epidemiological studies in different region of the world show the wide variation in HCV prevalence patterns (2). IDUs have now become the predominant source of HCV infection in developed and developing countries (18). Therefore for controling HCV infection in general populations, we need to manage and control the infection in these groups of patients.

In this present study we showed that genotype $3 a(58.3 \%)$ was the predominant genotype followed by $1 \mathrm{a}(25 \%)$ and $1 \mathrm{~b}$ (16.7) among IDUs. Our results were similar to the results of another report from Iran that revealed the predominant HCV genotype in Iranian IDUs to be $3 \mathrm{a}(54 \%)$ (19). similar Another study in Iran showed that HCV genotypes $1 \mathrm{a}(40 \%)$ and $3 \mathrm{a}(37 \%)$ were the most frequent in Ira- nian IDUs (20). A recent similar study in Lebanon showed that HCV genotype 3 was predominant (57.1\%), followed by genotype $1(21.4 \%)$, and genotype $4(17.9 \%)$ in Lebanese IDUs (22).

Genotype 3a is significantly associated with transmission through injection of drug in industrialized countries, and this explains the prevalence of 3a in many North and South American and European countries , where injection of drug use is common (23). The molecular epidemiology of HCV-3a in IDUs in these countries suggested that HCV-3a has been spread from a common origin through a unique worldwide epidemic, which rapidly spread among the drug user communities transmitting HCV-3a throughout the world (24).

Our results showed that it seems that there is high similarity between the pattern of HCV genotype in IDUs in Iran and Europe as it had showed in the report from Lebanon (22). Lebanese authors suggested that HCV genotype 3a could have been introduced to Lebanese IDUs population from Europe, whereas some of American and European authors reported that the HCV genotype 3 originated from Asia, and then it has widely spread among IDUs (24). The data that indicate the predominant HCV genotype among IDUs in neighboring Middle -East countries is still limited and controversial $(19,20,22)$.

The geographical origin of HCV-3a is not clear, because sera archived in the last decades are not available. Also worldwide prevalence of HCV-3a and mechanisms of its transmission are not accurately defined, therefore, epidemiologic studies are needed for better understanding of this issue. The main route of HCV transmission is through IDUs, who are very spread in our population. It is very likely to change the frequency of specific genotype in HCV- infected patients from 1a to 3a, as another study suggested (19), but further studies on large number of IDUs are necessarily needed.

In conclusion, our study showed that in chronic HCV infected IUDs in Tehran,the subtype $3 a$ is the most frequent .This information could have epidemiological significance and would be added to Middle-East regional network. Considering that HCV anti-viral therapy varies significantly with the genotype, this result may affect disease treatment and control.

\section{Acknowledgements}

We would like to thank the Research center of Iranian Blood Transfusion Organization, Tehran,Iran. The authors declare that they have no conflict of interests.

\section{Financial Disclosure}

None declared.

\section{Funding/Support}

None declared. 


\section{Authors' Contribution}

None declared.

\section{References}

1. Perz JF, Armstrong GL, Farrington LA, Hutin YJ, Bell BP. The contributions of hepatitis $B$ virus and hepatitis $C$ virus infections to cirrhosis and primary liver cancer worldwide. $J$ Hepatol. 2006;45(4):529-38

2. Rosen HR, Martin P. Viral hepatitis in the liver transplant recipient. Infect Dis Clin North Am. 2000;14(3):761-84

3. Wasley A, Alter MJ. Epidemiology of hepatitis C: geographic differences and temporal trends. Semin Liver Dis. 2000;20(1):1-16

4. Cheraghali AM, Abolghasemi H. Plasma fractionation, a useful means to improve national transfusion system and blood safety: Iran experience. Haemophilia. 2009;15(2):487-93

5. Alavian SM, Adibi P, Zali MR. Hepatitis $C$ virus in Iran: Epidemiology of an emerging infection. Arch Iranian Med. 2005;8(2):84-90

6. Alavian SM, Fallahian F, Lankarani KB. Comparison of Seroepidemiology and Transmission Modes of Viral Hepatitis B in Iran and Pakistan. Hepat Mon. 2007;7(4):233-238

7. Alizadeh AHM, Alavian SM, Jafari K, Yazdi N. Prevalence of hepatitis $C$ virus infection and its related risk factors in drug abuser prisoners in Hamedan-Iran. World J Gastroenterol. 2005;11(26):4085

8. Hajiani E, Masjedizadeh R, Hashemi J, Azmi M, Rajabi T. Hepatis C virus transmission and its risk factors within families of patients infected with hepatitis $C$ virus in southern Iran: Khuzestan. World J Gastroenterol. 2006;12(43):7025-8

9. Zamani S, Ichikawa S, Nassirimanesh B, Vazirian M, Ichikawa K, Gouya MM, et al. Prevalence and correlates of hepatitis C virus infection among injecting drug users in Tehran. Int J Drug Policy. 2007;18(5):359-63

10. Simmonds P, Bukh J, Combet C, Deleage G, Enomoto N, Feinstone $\mathrm{S}$, et al. Consensus proposals for a unified system of nomenclature of hepatitis C virus genotypes. Hepatology. 2005;42(4):962-73

11. Pawlotsky JM. Treating hepatitis $C$ in "difficult-to-treat" patients. N Engl J Med. 2004;351(5):422-3

12. Zein NN. Clinical significance of hepatitis $C$ virus genotypes. Clin Microbiol Rev. 2000;13(2):223-35
13. Kurbanov F, Tanaka Y, Sugauchi F, Kato H, Ruzibakiev R, Zaly alieva $\mathrm{M}$, et al. Hepatitis C virus molecular epidemiology in Uzbekistan. J Med Virol. 2003;69(3):367-75

14. Simmonds P, Holmes EC, Cha TA, Chan SW, McOmish F, Irvine B, et al. Classification of hepatitis $\mathrm{C}$ virus into six major genotypes and a series of subtypes by phylogenetic analysis of the NS-5 region.J Gen Virol. 1993;74 ( Pt 11):2391-9

15. Ahmadi Pour MH, Keivani H, Sabahi F, Alavian SM. Determination of HCV genotypes Iran by PCR-RFLP. Iranian J Publ Health. 2006;35(4):54-61

16. Amini S, Majd Abadi MM, Alavian SM, Joulaie M, Ahmadipour MH. Distribution of Hepatitis C Virus Genotypes in Iran: A Population-Based Study. Hepat Mon. 2009;9(2):95-102

17. Sharifi Z, Shooshtari MM, Kermani FR. Identification of HCV genotypes in HCV infected blood donors. Indian J Microbiol. 2010;50(3):275-9

18. Shepard CW, Finelli L, Alter MJ. Global epidemiology of hepatitis C virus infection. Lancet Infect Dis. 2005;5(9):558-67

19. Samimi-Rad K, Nategh R, Malekzadeh R, Norder H, Magnius L. Molecular epidemiology of hepatitis $\mathrm{C}$ virus in Iran as reflected by phylogenetic analysis of the NS5B region. J Med Virol. 2004;74(2):246-52

20. Kabir A, Alavian SM, Keyvani H. Distribution of hepatitis C virus genotypes in patients infected by different sources and its correlation with clinical and virological parameters: a preliminary study. Comp Hepatol. 2006;5:4

21. Ohno O, Mizokami M, Wu RR, Saleh MG, Ohba K, Orito E, et al. New hepatitis $\mathrm{C}$ virus (HCV) genotyping system that allows for identification of HCV genotypes 1a, 1b, 2a, 2b, 3a, 3b, 4, 5a, and 6a. J Clin Microbiol.1997;35(1):201-7

22. Mahfoud Z, Kassak K, Kreidieh K, Shamra S, Ramia S. Distribution of hepatitis $C$ virus genotypes among injecting drug users in Lebanon. Virol J. 2010;7:96

23. Roman F, Hawotte K, Struck D, Ternes AM, Servais JY, Arendt V, et al. Hepatitis $\mathrm{C}$ virus genotypes distribution and transmission risk factors in Luxembourg from 1991 to 2006. World J Gastroenterol. 2008;14(8):1237-43

24. Morice Y, Cantaloube JF, Beaucourt S, Barbotte L, De Gendt S, Goncales FL, et al. Molecular epidemiology of hepatitis C virus subtype 3a in injecting drug users. J Med Virol. 2006;78(10):1296-303 